\title{
Teaching as Creative Process: Perspectives From Personal Narratives
}

\author{
Charlotte L. Doyle
}

Sarah Lawrence College, USA

E-mail address: cdoyle @slc.edu

\section{ARTICLE INFO}

\section{Keywords:}

Creativity

Teaching

\section{Article history:}

Received 9 October 2016

Received in revised form 4 February 2017

Accepted 6 February 2017

ISSN: 2354-0036

DOI: 10.1515/ctra-2017-0001

\section{A B STRACT}

This paper explores the place of teaching in the landscape of creativity. It draws on analyses of interview narratives from dedicated teachers from various educational levels and teaching contexts; none had been singled out as creative by their institutions. Asked when teaching had been experienced as a creative process, rather than describing specific incidents, the teachers told of projects and goals that spanned a semester or year. Daily activities contributed to the projects, making creativity in teaching everyday creativity in both the technical and literal senses. Interview protocols were analyzed into meaning units and categorized into themes. Some themes were similar to those in studies of creative teachers and teaching, though no prior study explicitly put forward all of them. The interviewed teachers described practices previously suggested for nurturing student creativity. Most themes echoed features found in creativity studies of various other domains. Two unique features were the double nature of intrinsic motivation and the nature of the creative "product."

Where does teaching fit into the vast and varied landscape of creativity? One way of capturing creativity's variety has been partitioning it into categories: Big-C creativity (Csikszentmahilyi, 1996) consists of creative achievements recognized by a field as changing a domain. Pro-C creativity refers to having reached professional level expertise in a creative field (Beghetto \& Kaufman, 2010b). Local creativity is defined as creative achievement recognized by local institutions (Reilly, Lilly, Bramwell, \& Kronish, 2011). Everyday creativity is originality in any endeavour that is meaningful to someone else (Richards, 2011). Mini-c creativity consists of novel and personally meaningful interpretations of ex- 
periences, actions, and events often during the process of learning (Beghetto \& Kaufman, 2007). An initial hypothesis of the present study was that experiencing the creative process in teaching is not limited to those singled out as creative either locally or by an entire field; rather, dedicated teachers not explicitly recognized as creative are likely to experience creative episodes.

Doyle (2011) proposed that the discrete categories of creativity could be considered regions on a series of dimensions which could capture other features of creative episodes as well. For example, the magnitude of recognition dimension spans the categories from mini-c to big-C with all the possibilities in between. Other proposed dimensions were the length of the creative episode, its integrative complexity, degree to which initial project representation is structured, number of co-creators, and distribution of responsibility among them. This paper will explore these dimensions in creative episodes in teaching.

Another way of differentiating creativity studies is by their focus (Rhodes, 1961) - on person, process, product, or press (creative environment). For example, Amabile (1996, 2001) characterized the creative person as having creativity relevant dispositions (such as work style and personality characteristics), domain relevant skills (such as knowledge and technical skills), and intrinsic motivation.

Amabile (1996) is also a pioneer in the study of creative environments; her studies demonstrated that making intrinsic motivation salient typically enhances the creativity of products. Csikszentmihalyi (1996) noted that creative work is always in the context of a domain (content area) and field (cultural institutions that provide opportunities for and barriers to creative work) - another way of looking at the issues surrounding press. Press also emerged as a theme in the Reilly, Lilly, Bramwell and Kronish (2010) study. The creative teachers in their sample noted that school administrators often supported their teaching innovations and, when they did not, the teachers spoke of it as limiting their creative teaching. The paper will take note when teachers describe instances when school policies, administrators and colleagues facilitated the creative process in teaching, when they inhibited it, and how the teachers responded.

Focusing on the person aspect, Reilly, Lilly, Bramwell and Kronish (2010), summarized findings from case studies of award-winning teachers; they found creative teachers to display well-developed interpersonal awareness and skills and to be intrinsically motivated by a value-based orientation. In elaborating these categories, they pointed to characteristics such as balancing risk with secure structures and seeking student learning other than rote. Note that many of the descriptors refer to what creative teachers do rather than what they are. The current study explores the extent to which dedicated teachers not 
identified as creative by their institutions point to similar behaviour as they describe experiences of the creative process.

Some studies have looked at facets of process. Jaskyte, Taylor and Smariga (2009) asked university students and teachers to rank various descriptors of innovative teaching. There was considerable agreement on the top five descriptors among the university professors: gets students to learn how to construct knowledge themselves, is open to new ideas, is original - looks for new ways to present class material, is knowledge motivated, is up to date on scholarship, and evaluates the effectiveness of their innovative teaching methods. The student list of descriptors was different: engages students and responds to their feedback, is enthusiastic - conveys a genuine interest and fervour for the subject matter, encourages students to think outside the box, makes students excited about learning, and is open minded. In several papers, Sawyer $(2004,2015)$ suggested that creative teaching involves improvisation in the classroom and creating opportunities for students to construct knowledge. This current study asked teachers for descriptions of specific incidents over time, rather than to reflect on the features of innovative teaching.

The creative "product" in teaching has rarely been a focus. This study explicitly asked teachers to articulate their sense of the creative product in teaching. Their answers have implications for placing teaching according to a third way of organizing creativity studies, by their content domains (see, for example, Kaufman, \& Baer, 2005).

Much of the work on creativity in the context of education has been to explore ways in which teachers can facilitate student creativity. A collection of papers on nurturing creativity in the classroom (Beghetto and Kaufman, 2010a) put forward a number of suggestions including: fostering active learning and knowledge building (Sawyer, 2010), providing students with opportunities to solve meaningful problems (Fairweather \& Crammond, 2010) and to create (Sternberg, 2010; Runco, 2010a; Hennessey, 2010); encouraging and mentoring students (Sternberg, 2010; Richards, 2010; Renzulli \& De Wet, 2010); and allowing students to feel in control (Hennessey, 2010). An issue to be explored is the relationship between teaching that is experienced as creative and practices that facilitate student creativity.

The current study began with the assumption that dedicated teachers who had NOT been singled out as creative nevertheless experienced the creative process in the course of their teaching. The study thus has an affinity to the approach of Sternberg, Conway, Ketron, and Bernstein (1981) who asked ordinary people to list behaviors characteristic of intelligence and compared them to those recognized by psychologists. In this case, the teachers themselves, through their descriptions, were given the opportunity to reveal their 
implicit ideas of what constitutes creative behaviour in teaching. Their "lay" concepts will be compared to those psychologists have put forward with respect to creative teaching. On the other hand, the teachers were not asked to reflect on a concept as in the Sternberg et al. study. Instead, taking a narrative/phenomenological approach (Csikszentmihalyi, 1996; Franklin, 1994), the teachers were asked to describe episodes in detail as they unfolded over time. This allowed features of the creative process in teaching for each teacher to emerge principally via induction in the tradition of grounded theory (Glazer \& Strauss, 1967).

Psychologists studying creativity have disagreed on the possibility of making generalizations. Gruber and Wallace (2001) asserted that the work of every creative person is unique. Most other approaches seek to identify common features of the creative process at least within domains (Kaufman \& Baer, 2005). Through interviews, the current study listened to the voices of individual teachers; a more formal analysis of the protocols enquired into the extent to which the teachers' unique experiences revealed common themes.

\section{METHOD}

The selection of schools from which to recruit teachers was guided by theoretical sampling (Glazer \& Strauss, 1967), choosing different contexts to study the same phenomenon. The schools varied in the educational level - primary school, high school, and college and teaching contexts - a progressive public primary school in a wealthy suburban community, a traditional primary school in which almost all the students were low income and Latino, a public high school in a diverse suburb close to a major city, and a liberal arts college.

Professionals familiar with various educational contexts were asked to recommend dedicated teachers, ones who were conscientious about their work. The word "creative" was not part of the request and did not enter into the conversation in any way. After chatting informally with the liberal arts college Dean about the pedagogy at her school, she was asked to recommend both a lecturer and seminar teacher.

The first five teachers contacted agreed to be interviewed. Fortuitously, they represented another variation among the teachers. The two primary school teachers had less than 5 years of experience whereas the other three had over 10 years.

Since the aim was to have the teachers convey occasions when they felt creative, the interviewer did not define the creative process. As in the study by Sternberg and his colleagues concerning lay people's concepts of intelligence, the aim here was to grasp what teachers experienced as the creative process. Thus, all the interviews began with the question, "When has your teaching felt like a creative process?" Thereafter, there was no fixed order of questions; instead the aim was to get a rich description of experience, to 
get, as Giorgi (2009, p122)) put it "as complete a description as possible of the experience that a participant has lived through". The interviews ended with a reflective question, "What is the outcome, the product of the creative process in teaching - the counterpart of the artist's painting or the musician's performance?" Each of the interviews was about two hours long. The interviews were digitally recorded and transcribed.

Each transcript was reread several times to get a sense of the duration and shape of the creative episodes in teaching for each teacher. The transcripts were then broken down into meaning units following the procedures put forward by Giorgi, $(1997,2012)$. Based on these, each teacher's interview was summarized to capture the individual experiences of each teacher. The meaning units were then categorized into general themes, providing the basis for identifying common features amid the variety in the episodes described by the different teachers.

The method for verifying the author's reports of the teacher's descriptions was member validation (Kvale \& Brinkmann, 2009). The relevant sections of the paper were presented to the participating teachers; they were asked read them over, to point out where something was missing or needed to be changed, and to verify the accuracy of the rest.

\section{FINDINGS}

All the teachers verified as accurate the author's report of their descriptions which appear below. There were no suggested changes or additions.

Each interviewee described the experience of teaching as a creative process differently. Sue, a second grade teacher immediately identified the year she read The lion, the witch and the wardrobe (Lewis, 1950) to her class, chapter by chapter. The students were fascinated, and she noticed that the children drew on characters, events and settings in their free writing and art work. She then made the book the theme for all aspects of the year's curriculum including teaching punctuation and maths. The culmination of the work was the children's planning and acting out an improvised play based on the book, an activity in which they, as well as the teacher, found solutions to problems as they emerged.

Don, a fifth grade teacher in the school with a low income population, described his College Bound programme, an afterschool activity he invented for all fifth grade students in his school. The impetus was his noticing that many children were bored with the required curriculum. College Bound was open to all who agreed to do their homework and cause no behavioral disruption in their classrooms. The programmed consisted of two week modules on topics such as advanced maths, poetry, history and art history. Though colleagues discouraged him from getting the programme started, saying no students would be interested, it later met with enthusiastic responses from students and support from his colleagues and his principal. 
Fred was a special education high school teacher; he had a class of eight, including a child diagnosed with Asperger's Syndrome, a student with ADD, and several students who were there only because they were considerably below grade level in reading. He responded to the question, "When has teaching felt like a creative process?", with the answer, "Every day." When asked to elaborate he answered, "You have to figure out what the students need and give it to them." Each student was a challenge for him, a problem he had to solve over the course of the year. In addition, he spoke of his frustration with the textbooks he was given, his use of newspapers as a major source for his teaching, his tailoring reading lessons to the interests of individual students, his demand that pairs of students work together on research projects, and his fashioning his own way of preparing students for the required state tests: in the last two weeks of the semester; he gave and went over practice test after practice test.

Bev, a college seminar teacher, also responded to the question, "When has teaching felt like a creative process?", with the answer, "Every day." For her, the seminar process itself felt creative. She gave examples of students struggling to put their understanding of readings into speech, their relating what they were reading to earlier material or material from other courses, and their finding connections between academic reading and their own experience. Asked to explain, she said that there was a "creative process going on around the table" which she as a teacher was enabling and facilitating. On the spur of the moment, she had to find the balance between standing back and control. She also emphasized that the creative process was cumulative with a successful seminar becoming increasingly creative over the course of the year as the students became more and more active in their learning and their conversations.

Jay, a college lecturer found every aspect of teaching to exemplify the creative process. From creating a syllabus for his course in the history of drama, to daily class preparation which involved both re-reading plays and the latest scholarship, to planning his lectures which aimed at cumulatively building a foundation for thinking about plays, his improvisations on his notes in class, to the way he designed his tests. Though he did most of the talking in the lecture hall, he encouraged questions which sometimes resulted in his finding himself saying something unplanned and surprising to him. He was also alert to whether the students were engaged or slipping away. He spoke of respect for the material as his starting point and of abandoning a very successful course because it felt as if it were going stale.

The unique quality of each teacher's experience was also reflected in the themes, some unique to one interviewee, some shared with several but not all. For example, only Fred specifically mentioned using an extrinsic incentive, grades, as part of his description 
of his creative process. Nevertheless, the categorization of meaning units into more general themes also revealed similarities. For example, here are some meaning units which were categorized under the theme, sensitivity to problems and problem solving. Sue, the second grade teacher said, "I noticed what they were writing. I noticed if we were going to do punctuation, what they needed. They needed periods, they needed exclamation points, they needed question marks and they needed quotation marks." Jay said, "I'm sure it has happened that the odd student somewhere along the line has stolen an essay off the internet and has given it to me and it has gone by me, but I do what I can to prevent that - and not just simply by being a watch dog, but by asking questions that do not exist on the internet." Other examples of meaning units are quoted or paraphrased in the discussion of specific themes.

\section{Common Interview Themes}

The creative process as nested. For these interviewees, the answer to the question, "When has teaching felt like a creative process?", turned out to be complex. The author's initial assumption was that each teacher would speak of particular incidents as feeling creative and each interviewee did. The lecturer spoke of feeling creative as he put together his syllabus and pinpointed an improvisational moment in the classroom when he invented a new way to demonstrate the physicality of the Greek chorus - having 12 students come forward and stamp their feet in unison. The seminar teacher remembered a particular class in which she was able to facilitate a free yet engaged and informed discussion about the controversial subject of race. The special education teacher spoke of finding a newspaper article that he thought would be meaningful to a student who had been reluctant to read. The fifth grade teacher described an art museum trip and the activities he invented to deepen the experiences there for his College Bound students. The second grade teacher recalled the time an insight came to her about how to frame a writing assignment and the occasion when she invented a role for a child who burst into tears when she failed to be elected by the class to play the role she coveted. These special moments could take place anytime throughout the teacher's day - during preparation, in the midst of being face-to face with students, at home while doing other tasks. Generally these moments represented solving specific problems. Sometimes the solutions were improvised; other times they involved a period of reflection. Yet, for these teachers, the boundaries of the creative process were not limited to discrete incidents. These creative moments were sub-episodes, "chapters and scenes," in the course of a semester or a year which felt like a cumulative creative process. Looking for articles that would interest students reading below grade level was part of the larger project of engaging each 
of the students who had failed in regular classrooms. A unit on art history was part of the larger project of challenging students who were bored. Finding the balance between allowing free interaction and teacher guidance during a particular class was part of the larger project of creating a space where students felt safe enough to ask questions, share confusions, and probe material more deeply. Solving the problem of a child unhappy that she was not cast in a play was part of the larger project of sharing passion for a book in a way that met a number of educational goals. Improvising a new way to make the idea of the Greek chorus come alive was part of the larger project of helping students grasp the nature of theatre in different eras. This feature - a sustained creative project with creative sub-episodes embedded in it - has been called nested (Doyle, 2011).

Adaption to demands and opportunities of domain and field. Fred had to deal with the conflicting demands posed by special education students unable to benefit from standard methods, an assigned textbook that children found boring, an educational system that evaluated through standard tests, and his own educational values. Others also spoke of the demands and opportunities of the contexts in which they were teaching. Sue, who had the opportunities offered by an administration friendly to progressive methods, also knew the demands of the standard second grade curriculum. Don developed his College Bound programme in response to his frustration with the fifth grade curriculum he was required to teach. Bev taught in an institution in which teachers were expected to make seminar teaching interactive and in an era when issues of race and class were both difficult topics and lively research areas. Jay noted the limits and opportunities of teaching in lecture format and constantly renewed his knowledge of current scholarship. Whether enjoying the support of their institutions or finding ways to meet their own goals in the face of conflicting institutional demands, part of the creative challenge was to adapt to the demands and to use the opportunities arising from the contents they needed to teach and the contexts in which they taught.

Preparation. Fred said of teaching, “You can't go in and just wing it. Teaching is a creative process that requires an awful lot of preparation." All the teachers detailed their careful preparation in the light of overall plans. Sue described how she planned activities based on the shared book, met curricular requirements and aimed at correcting what she saw as less successful writing assignments in the past. Don described planning two week modules for his after-school programme. Jay described his design of his syllabus itself as a creative process, resembling planning for the chapters of a book. Preparation per se does not guarantee a creative process; but these teachers experienced preparation as an indispensable part of it. 
Improvisation in the classroom. All the teachers prepared, hypothesized about the effect of various strategies and planned the content of their classes. Still, every day, they improvised - made unplanned, spontaneous responses to what was happening in the classroom. Some moments of improvising felt especially creative - inventing a role on the spot for an unhappy child, finding the balance between allowing free discussion and control at a particular moment in a seminar, giving a strategy to an ADD student who announced he forgot his pills, coming upon a new way to make the experience of being the audience in Greek theatre meaningful in the course of lecturing.

Students as co-creators. Bev emphasized that her creative process involved establishing with her students the ground for engaged, informed, group exploration; "The creative process was going on around the table." Sue explained how the reactions and suggestions of her second-grade students shaped the play they were constructing and referred to it as "our creative process." Don, on the spur of the moment, moved in new directions based on what his students said and did. Fred felt creative as he saw students to whom he gave a common project working together effectively. Even Jay, the lecturer, spoke of the continual impact of the students on his teaching through their responses and questions as he lectured. A major occasion when teaching felt especially creative was when it unfolded as an improvisation co-created with students.

Listening. Don said, "Teaching is as much about listening as talking." All the teachers mentioned listening in the broad sense - attending to what the students said and did. It could involve watching faces closely, noticing boredom or engagement, hearing how students articulated the concepts of assigned reading, sensing a student's fear, anxiety or distress. When the context allowed, their close attention to students involved getting to know them individually. Teachers from all four levels spoke of listening in this broad sense as essential to their creative process.

Creating student opportunities for active construction and creativity. Each of the interviewed teachers brought up activities they designed, giving students opportunities to construct something of their own. Sue spoke of being in awe of the poems her students wrote in response to the shared book. Don felt creative when, after an art museum trip which included impressionist work, a child took a handful of coloured pencils and drew with the handful to show the colour of the sky. Fred noted that two children, whose project was to make a presentation on religions, went beyond the four major religions discussed in the text and included some lesser known ones. Bev spoke of feeling creative when a student's research paper she was guiding on synaesthesia came together. Jay felt creative when his students were able to use what they had learned from his lectures to construct original essays. 
Sensitivity to problems and problem solving. The teachers all spoke of identifying problems they needed to solve. Sometimes the problem finding took place via active exploration such as searching for new ways to structure classroom activities. Other times, the teachers were confronted by problems - a student who forgot his pills, a child bursting into tears, or boredom or puzzlement on faces. The teachers sometimes improvised a solution at the moment they became aware of the problem. Sometimes the problems required reflection and planning - how to approach a seminar discussion on a sensitive topic or how to frame a second grade writing assignment.

Experimentation. We think of the sciences when we speak of experimentation, but each teacher also described making hypotheses about how a given approach would work and then trying it out. Sue knew student writing could be thin if her students didn't take time to think. She experimented with each student coming up to her individually and whispering their ideas in her ear. Fred experimented with different pairings of students assigned to do projects together. Don tried out new possibilities when he saw his students "didn't get” what he was teaching. Bev experimented with allowing her students to choose the final unit's subject for her course. Jay spoke of experimenting with an entirely new course.

Failure and renewed problem solving. Experiments do not always come out as expected. Though the wording of the initial question encouraged teachers to tell success stories, the interviewees also brought up their failures - the special education student whom the teacher couldn't reach, the fifth grade students who did not "get it," the seminar that did not meet the teacher's goals, the second grade writing assignment that resulted in inferior work, the lecture that went stale. These failures became new problems to be solved, requiring reflection, thoughtful planning and new experimentation.

Deep task engagement. The productive response to failure was an indication of deep task engagement. Another was incubation (Wallas, 1926) - solutions to teaching problems coming to mind at odd moments when the teachers were engaged in the other tasks of daily life. Additional evidence came from statements such as, "I became lost in the work" and "my mind was racing with what needed to be done next." The lecturer, describing what he sometimes experienced as he was speaking, said this:

There's this realm where you're not wholly yourself, you're not trapped anymore within even - well, your own body, your own consciousness...this sense that you have - you're riding a wave...there's power which has come to you...(you are) being led along. And that is very exhilarating because it seems as if you are experiencing energy which is not just simply your own. 
This description fits many of Csikszentmihalyi's $(1990,1996)$ criteria for flow a sense of having entered a reality different than the everyday, characterized by spontaneity, loss of self-consciousness and letting go of conscious control - further evidence of deep task engagement.

Intrinsic motivation: Teaching as a double passion. The interviewed teachers in this study gave evidence of a double passion as they spoke of the times they experienced the creative process. They loved what they were teaching - history in relation to current events, a beloved book, masterpieces of the arts, psychology, dramatic literature. The lecturer called teaching "a communication of love." They were also intrinsically motivated to further the intellectual growth and well-being of their students. This double passion sustained them as they took risks and sometimes failed. More often they succeeded in bringing their two passions together, finding ways to share material about which they felt passionate with young people to whom they were committed.

The "Product": Student Transformation. Runco (2010b) suggested that a common feature of the creative product in all domains is transformation. When the teachers were asked, "What is the "product, the outcome of the creative process in teaching?" they did not speak in terms of transforming the educational domain with an original innovation. They often spoke of borrowing and adapting ideas from elsewhere. Instead, they saw their creative product as a different kind of transformation, a transformation in the students. In speaking of the students who had not been able to learn in standard classrooms, the special education teacher said, "They come to know the process. It's not easy to be a learner, but it has its rewards for me and them." He also spoke of his work with them as putting them on a path for becoming "happy, lifetime learners, responsible for others and successful in their lives." The second grade teacher found that the book that shaped her year with the students had "huge curricular, social and emotional outcomes." It had shown her children that "they had strengths they didn't know they had;" at the same time "it expanded their worlds". The fifth grade teacher first answered in terms of academic understanding, whether the students "got it." But he went on to say that he wanted the students to feel successful, for them to see their capabilities and possibilities in a new way; hence the title, College Bound, for his programme. For the lecturer, the aim was for students to have discovered new ways of thinking about plays, about literature in general, and about life beyond; he structured his final writing assignment so that they were challenged to think creatively in these new ways. The seminar teacher could have been speaking for all the others by saying, "The outcome is transformation ...sometimes in relation to the content of the material, experiences of transforming the understanding of the 
material, ownership...When it goes deeper, it often follows from that. They realize that it has changed their relation to learning in their own lives...they've been transformed as learners."

The common features of the creative process and its product as described by teachers are listed in Table 1.

\section{Table 1}

Features of the creative process and its product in teaching

The creative process as nested

Adaptation to the demands and opportunities of domain and field

Preparation

Improvisation in the present

Students as co-creators

Listening

Creating opportunities for student construction and creation

Sensitivity to problems and problem solving

Experimentation

Failure and renewed problem solving

Deep task engagement

Intrinsic motivation for the material taught and for student well-being

Student transformation as goal and "product"

\section{DISCUSSION}

The interview themes have implications for thinking about the place of teaching in the realm of creativity. The features that emerged from the teachers' descriptions can be compared to those found in other studies of creative teaching, to findings from research in other creative domains, and to practices which have been suggested for enhancing student creativity. These and other issues will be discussed as answers to a series of questions.

\section{What do models suggest about the place of teaching in the realm of creativity?}

According to the category model (Beghetto \& Kaufman, 2007), creative episodes in teaching, as these teachers described them, were examples of everyday creativity. The technical meaning according to this model is that the product is both original and meaningful to someone else (Richards, 2011). The teacher's work, adapted to and co -created with students, was new and meaningful to students as it unfolded. Often, no one else was aware of the creative process unfolding in their classrooms. 
The teachers' work was everyday creativity in the literal sense, too. The teachers spoke of their daily work - their work every day - as part of a larger creative endeavor.

The introduction pointed out that the dimensional model (Doyle, 2011) suggested that the categories - mini-C, everyday creativity, local creativity, pro-creativity and big-C creativity - could be considered regions along continuous dimensions. A major criterion for placement in one of these categories is the magnitude of recognition the creative product receives. The magnitude of recognition was low for the interviewed teachers; most of their work was not recognized outside their classrooms, though the fifth grade teacher noted some local recognition from his principal, fellow teachers and school staff, moving him a little higher on that dimension. Another criterion for Big-C creativity is that the recognition is for changing a domain; the work of the teachers interviewed did not change the domain of education. Converting that all-or none trait into a dimension, Doyle (2011) named it the degree to which a structure has been transformed. In the case of the teachers, the teachers' place on this dimension is hard to establish. The structures transformed were not public events, but transformations in the being of the students. Standardized tests can only hint at the ways in which the students' cognitive and emotional structures changed.

The dimensional model points to ways in which creative episodes which technically fall in the same category can be differentiated. Take the creative projects of the teachers in comparison to someone who spends an afternoon designing an original birthday card for a friend. That episode and the interviewees' nested episodes of teaching as a creative process differ radically on the dimension, length of the creative episode - a few hours versus a semester or a year.

\section{How do the different teachers' episodes compare on the dimensions?}

The teachers' episodes were similar on some dimensions - length of the creative episode (as noted before) - and varied only to a degree on number of co-creators. The dimension, degree of structure in the episode's domain, reflects how difficult or easy it is to determine whether any creative product constitutes a contribution to a particular domain - with mathematics highly structured and child-rearing relatively unstructured (Csikszentmihalyi, 1996); the teachers were similar on this dimension in that teaching is a loosely structured domain. All the teachers' deep task engagement suggested that their creative projects made an important contribution to sense of identity and played a major role in the network of enterprises. On the other hand, the teachers varied in degree of structure in initial project representation - from the carefully constructed syllabus of the lecturer to the emergent curriculum of the second-grade teacher. Their work also varied in integrative com- 
plexity - some designing integrated units over several weeks, others, such as the second grade teacher, integrating over the entire year. On the degree of role differentiation dimension, all the teachers, including the lecturer, when they spoke of their teaching as co-creation, saw their roles as clearly differentiated from that of the students. The distribution of responsibility varied, with the lecturer taking the most responsibility and the others giving varying amounts of responsibility to students.

\section{Was the small, non-random sample a limitation of the study?}

A major aim of this investigation was to get rich descriptions from the perspectives of teachers in order to gain insight into the possible shapes of the creative process in teaching over time. This kind of phenomenological study often involves interviewing only a small number of people to capture unique experiences in an area of focus as well as to suggest underlying similarities (Kvale \& Brinkmann, 2009). Furthermore, the teachers came from a single culture at a particular point in history. There is no claim that the five narratives are representative. To broaden the scope of generalization, further research is needed.

\section{Did these teachers describe practices suggested for nurturing student creativity?}

The answer is yes. The teachers fostered active learning and knowledge building (Sawyer, 2015); they created opportunities for problem solving (Fairweather \& Crammond, 2010) and for creative endeavours (Sternberg, 2010; Runco, 2010a; Hennessey, 2010). They encouraged and mentored their students (Sternberg, 2010; Richards, 2010, Renzulli \& De Wet, 2010). From the evidence of these five teachers, the features of the creative process as experienced by teachers are also features that nurture student creativity.

\section{How do the themes compare with findings of prior studies of creative teaching?}

The interviewed teachers had not been identified as creative. Yet, the features that emerged from their descriptions had related counterparts in at least one of the prior studies of teachers who had been explicitly identified as creative. No previous study cited all of them. Table 2 provides a summary. No other study referred to deep task engagement, though this feature may have been implicit. None of the studies pointed out the nested feature of the creative process in teaching because their focus was different; the other studies did not follow the creative process in teaching over time. 
Table 2

Features of teaching as a creative process in the current study and related

features put forward in earlier work

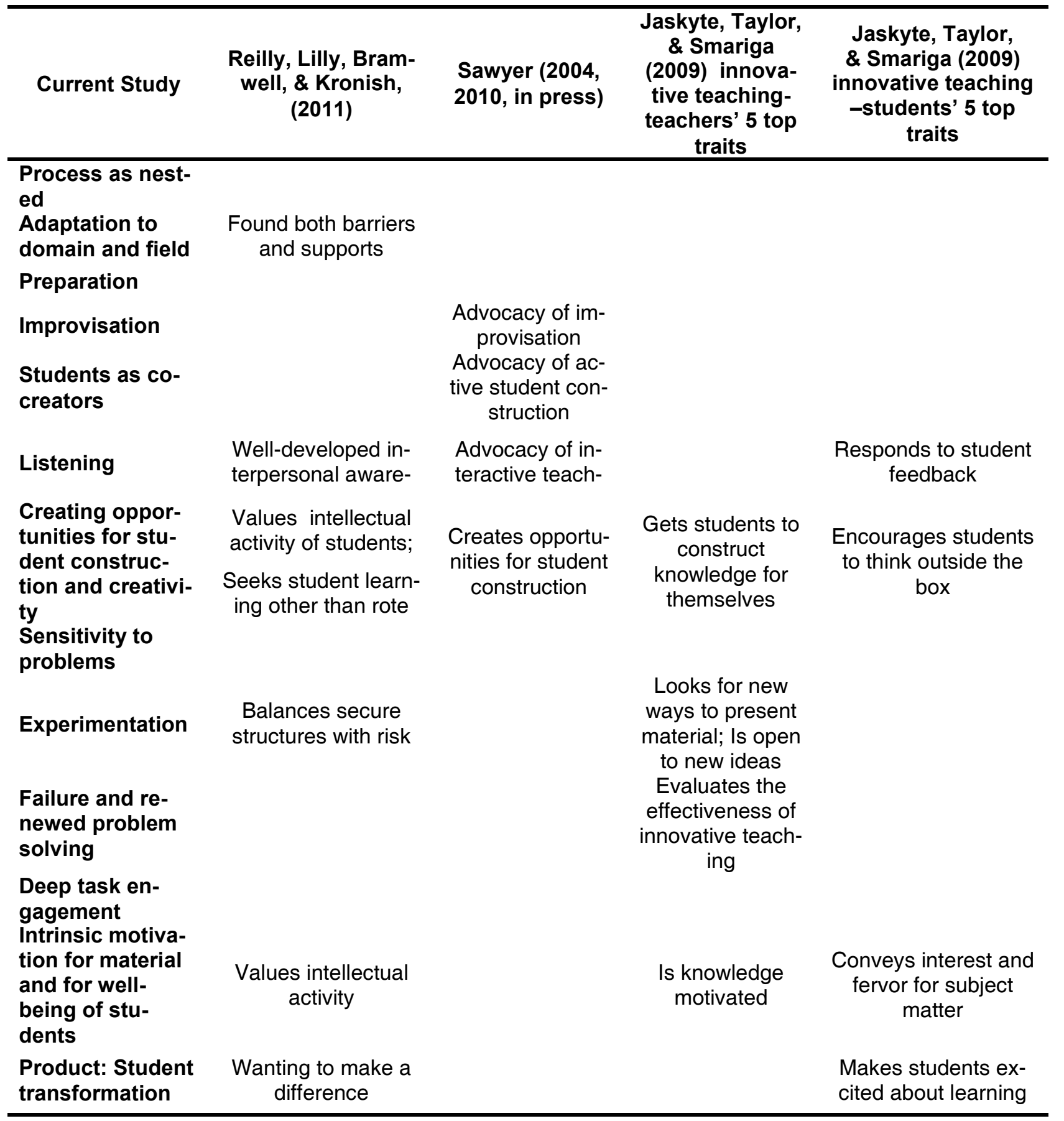

Were the interviewees creative teachers?

The convergence between the current findings and prior studies of creative teachers suggest that the interviewees could be considered creative teachers. The content of the interviews suggest this as well. But there are two important points to consider. First, the teachers had not been singled out by their institutions as creative. Second, before being asked the question, four of the five teachers had not applied the word "creative" to themselves or their work. Nevertheless, the teachers' answers to the original question, "When 
have you experienced teaching as a creative process?", were given immediately - within a few seconds. By asking when rather than whether, the question invited them to apply the term to their teaching. Thus, once the teachers were asked the question, they immediately saw its relation to their work. Bev spoke of this after the formal interview was over, but the recorder was still recording. She said: “I don’t think I necessarily would have used the words 'creative process' if you hadn't asked me to frame what I'm doing in that regard... but I absolutely experience creativity... making something out of the parts... bringing something into existence that didn't exist before." This implies that dedicated teachers, not singled out as creative by their institutions and without explicitly applying the term creative to their own work, are, in fact, creative teachers.

\section{Did the teachers' creative process descriptions resemble those from other domains?}

Most of the features have such counterparts in one domain or another. Nestedness is often a feature of creative work in the arts and the sciences (e.g., Gruber, 1981). The teachers exemplified Csikszentmihalyi's (1996) assertion that the creative process is always in the context of a domain and field. Gardner (1997) proposed that creators such as Freud and Graham set themselves against some of the expectations of domain and field - what Gardner called creative asynchrony - and there were examples of this as well among the teachers. Creativity investigators from Wallas (1926) to Amabile (1996) have identified preparation as an early step in their descriptions of the creative process; Berliner (1997) pointed out that the spontaneity of jazz depends on a lifetime of preparation and knowledge.

Improvisation has been noted as a feature of creative work in poetry (Piirto, 2005), fiction writing (Doyle, 1998) and jazz (Berliner's 1997). Berliner's (1997) interviews of jazz musicians highlighted the importance of listening, of getting to know the strengths and weaknesses of other players and noticing when a fellow player is doing something unusual or is having an off day. Sawyer \& Dezutter (2009) in their study of co-creation in improvisational theatre groups, pointed out the features of what they call "distributed creativity" - unpredictable outcome, moment-to-moment contingency, effect of any given action changeable by a consequent action, and collaboration by equals. The dimensional approach (Doyle, 2011) suggested that co-creation does not necessarily have to be a collaboration among equals - that roles and degrees of responsibility can vary as they do in film-making and theatre - and, as was already pointed out, in teaching. Even without all the qualities Sawyer and Dezutter (2009) put forward, for the teachers in the study, a major occasion when teaching felt especially creative was when it was improvised in interaction with students. 
Guilford (1959) identified sensitivity to problems as a factor in his structure of intellect model. Experimentation is, of course, the basic method of science, though some degree of experimentation goes on in all fields. Akin to scientists, teachers made guesses about how a practice would work (hypotheses) and then tried them out. Similarly, problem solving is a feature of almost all creative domains, whether solving the problem of the structure of DNA (Watson, 1968) or a compositional problem in painting a mural (Arnheim, 1973). Failure and renewed problem solving are often features of narratives of the creative process (Gruber; 1981; Doyle, 1998). Gardner (1997), on the basis of case studies of eminent creators, concluded that their ability to cope with setbacks was an important feature of their creative success.

Deep task engagement (Wertheimer, 1969) is a sine qua non of all complex creative projects sustained over time even in the face of frustration, both in the sciences and the arts. Commitment to a problem, frustration with the inability to solve it, a turning away (incubation), and coming to insight, are the steps Wallas (1926) put forward and they have been frequently documented in accounts of the creative process since (Ghiselin, 1952; Csikszentmihalyi, 1996).

Intrinsic motivation - as Amabile's (1996) work has shown again and again - is one of the most frequently mentioned features of the creative process. As Kaufman and Baer (2005b) pointed out, intrinsic motivation may appear to be a general feature of the creative process, but its contents - intrinsic motivation for a specific activity - will be very different in different domains. In the sciences and the arts, the passion that underlies creative work in a domain is typically for that domain. The passions of the teachers who experienced the creative process every day were double - both for the contents they were teaching and for the intellectual growth and well-being of students.

\section{What are the implications of the teacher's visions of their creative product?}

Though Runco (2010b) pointed out that a common feature of the creative process from mini-c to Big-C is transformation, the transformation the teachers sought did not take the same form as in other domains - a tangible object as in technology and most arts, public contribution to knowledge as in the sciences, a time-limited performance as in dance, music and theatre programmes, or insight new to someone's own experience as described in mini-c. The product was both profound and elusive, contributing to the transformation of students as learners and their development as human beings. Because of its elusiveness, this kind of outcome is hard to measure and recognize. And yet teachers themselves did recognize when their work contributed to student development in this way, and they found it deeply fulfilling. There are other activities, such as coaching, counselling and psychotherapy which share many of the qualities of the creative process in teaching. In these 
cases, too, the aim is transformation, transformation within the client through processes marked by sensitivity to problems, problem solving, improvisation, listening and co-creation.

\section{Concluding Thoughts}

This paper has shown that the descriptions of the creative process by dedicated teachers, who have not been singled out as creative, resemble the activities of those who have been identified as such. Such descriptions have many general features in common with the creative process in various fine arts, sciences and performing arts. The creative product in teaching is of a different order; teaching is one representative of a creative activity in which transformation in another person is the aim and outcome of the process. The creative process in teaching shares the general feature of intrinsic motivation with other domains, but the nature of that motivation is unique, combining passion for the subjects taught and being intrinsically motivated to facilitate student learning and development. Thus, the study also contributes to sorting out general, overlapping, and domain specific aspects of the creative process (Kaufman and Baer, 2005b). The experience of the creative process as described by teachers is a rich resource for exploring the place of teaching in the landscape of creativity.

\section{REFERENCES}

Amabile, T. M. (1996). Creativity in context: Update to "the social psychology of creativity". Boulder, CO, US: Westview Press.

Amabile, T. M. (2001). Beyond talent: John Irving and the passionate craft of creativity. American Psychologist, 56, 333-336.

Arnheim, R. (1973). The genesis of a painting: Picasso's Guernica. Oxford, England: U. California Press.

Beghetto, R. A., \& Kaufman, J. C. ( 2007). Toward a broader conception of creativity: A case for mini-c creativity. Psychology of Aesthetics, Creativity, and the Arts, 1, 73-79.

Beghetto, R. A., \& Kaufman, J. C. (Eds.). (2010a). Nurturing creativity in the classroom. New York, NY, US: Cambridge University Press.

Beghetto, R. A., \& Kaufman, J. C. (2010b). Broadening conceptions of creativity in the classroom. In R. A. Beghetto \& J. C. Kaufman (Eds.), Nurturing creativity in the classroom. (pp. 191-205). New York, NY, US: Cambridge University Press.

Berliner, P. (1997). Give and take: The collective conversation of jazz performance. In R.K. Sawyer (Ed.), Creativity in performance (pp. 9-41). Greenwich, CT: Ablex.

Csikszentmihalyi, M. (1990). Flow: The psychology of optimal experience. New York: Harper Collins.

Csikszentmihalyi, M. (1996). Creativity: Flow and the psychology of discovery and invention. New York: Harper Collins. 
Doyle, C. (1998). The writer tells: The creative process in the writing of literary fiction. Creativity Research Journal, 11, 29-37.

Doyle, C. (2011). Dimensions of the creative process: Old categories, new perspectives. Creativity Research Journal, 23, 51-59.

Fairweather, E., \& Cramond, B. (2010). Infusing creative and critical thinking into the curriculum together. In R. A. Beghetto, J. C. Kaufman, R. A. (Eds.), Nurturing creativity in the classroom. (pp. 113-141). New York, NY, US: Cambridge University Press.

Franklin, M. B. (1994). Narratives of change and continuity: Women artists reflect on their work. In M. B. Franklin, B. Kaplan, (Eds.), Development and the arts: Critical perspectives. (pp. 165-191). Hillsdale, NJ, England: Lawrence Erlbaum Associates, Inc.

Gardner, H. (1997). Extraordinary minds. Portraits of 4 exceptional individuals and an examination of our own extraordinariness. New York: Basic Books.

Getzels, J. W., \& Csikszentmihalyi, M. (1976). The creative vision: A longitudinal study of problem finding in art. New York: Wiley.

Ghiselin, B. (1952). The creative process: a symposium. Berkeley, CA: University of California Press.

Giorgi, A. (1997). The theory, practice, and evaluation of the phenomenological method as a qualitative research procedure. Journal of Phenomenological Psychology, 28, 235-260.

Giorgi, A. (2012). The descriptive phenomenological psychological method. Journal of Phenomenological Psychology, 43, 3-12.

Glazer, B., \& Strauss, A. (1967). The discovery of grounded theory: Strategies for qualitative research. London, UK: Weidenfeld \& Nicholson.

Gruber, H. and Wallace, D. (2001). Creative work: The case of Charles Darwin. American Psychologist, 56 (4), 346-349.

Guilford, J. P. (1959). Three faces of intellect. American Psychologist, 14(8), 469-479.

Hennessey, B. A. (2010). Intrinsic motivation and creativity in the classroom: Have we come full circle? In R. A. Beghetto, \& J. C. Kaufman, R. A. (Eds.). Nurturing creativity in the classroom. (pp. 329-361). New York, NY, US: Cambridge University Press.

Jaskyte, K., Taylor, H., \& Smariga, R. (2009). Student and faculty perceptions of innovative teaching. Creativity Research Journal. 21, 111-116.

Kaufman, J. C. \& Baer, J. (Eds.). (2005a). Creativity across domains: Faces of the Muse. Mahwah, NJ: Lawrence Erlbaum Associates.

Kaufman, J. C., \& Baer, J. (2005b). The amusement park theory of creativity. In J. C. Kaufman, \& J. Baer (Eds.), Creativity across domains: Faces of the Muse. (pp. 321328). Mahwah, NJ, US: Lawrence Erlbaum Associates Publishers. 
Kaufman, J. C., Cole, J. C., \& Baer, J. (2009). The construct of creativity: Structural model for self-reported creativity ratings. The Journal of Creative Behavior, 43, 119-134.

Kvale, S. \& Brinkmann, S. (2009). Interviews: Learning the craft of qualitative interviewing, Second Edition. Thousand Oaks, CA: Sage.

Lewis, C. S. (1950). The lion, the witch, and the wardrobe. NY: Macmillan.

Piirto, J. (2005). The creative process in poets. In J. C. Kaufman, \& J. Baer (Eds.), Creativity across domains: Faces of the Muse. (pp. 1-22). Mahwah, NJ, US: Lawrence Erlbaum Associates Publishers.

Reilly, R. C., Lilly, F., Bramwell, G., \& Kronish, N. (2011). A synthesis of research concerning creative teachers in the Canadian context. Teaching and Teacher Education, 27, 533-542.

Renzulli, J. S., \& De Wet, C. F. (2010). Developing creative productivity in young people through the pursuit of ideal acts of learning. In R. A. Beghetto \& J. C. Kaufman (Eds.), Nurturing creativity in the classroom. (pp. 24-72). New York, NY, US: Cambridge University Press.

Rhodes, M. (1961). An analysis of creativity. Phi Delta Kappan, 42, 305-310.

Richards, R. (2010). Everyday creativity in the classroom: A trip through time with seven suggestions. In R. A. Beghetto, \& J. C. Kaufman (Eds.), Nurturing creativity in the classroom. (pp. 206-234). New York, NY, US: Cambridge University Press.

Richards, R. (2011). Everyday creativity. In Runco, M. A. and Pritzer, S. R. (Eds.) Encyclopedia of Creativity Second Edition. (pp. 468-475). London: Academic Press.

Runco, M. A. (2010a). Education based on a parsimonious theory of creativity. In R. A. Beghetto \& J. C. Kaufman (Eds.), Nurturing creativity in the classroom. (pp. 235-251). New York, NY, US: Cambridge University Press.

Runco, M. A. (2010b). Empirical possibilities of the Personal Theory of Creativity. Paper delivered at the Create 2010 conference at St. Luis, Costa Rica, Jan. 7.

Sawyer, R. K. (2004). Creative teaching: Improvisation in the constructivist classroom. Educational Researcher, 33(2), 12-20.

Sawyer, R. K. (1997). Improvisational theater: An ethnotheory of conversational practice. In R. K. Sawyer (Ed.). Creativity in performance. (pp. 171-193). Greenwich, CT: Ablex. Sawyer, R. K. (2010). Learning for creativity. In R. A. Beghetto, \& J. C. Kaufman, (Eds.), Nurturing creativity in the classroom. (pp. 172-190). New York, NY, US: Cambridge University Press.

Sawyer, R. K. (2015). A call to action: The challenges of creative teaching and learning. Teacher's College Record, 117 (10), 1-34. 
Sawyer, R. K. \& Dezutter, S. (2009). Distributed creativity: How collective creations emerge from collaboration. Psychology of aesthetics, creativity, and the arts, 3, 81-92.

Sternberg, R. J. (2010). Teaching for creativity. In R. A. Beghetto \& J. C. Kaufman (Eds.), Nurturing creativity in the classroom. (pp. 394-414). New York, NY, US: Cambridge University Press.

Sternberg, R. J., Conway, B. E., Ketron, J. L., \& Bernstein, M. (1981) People's conceptions of intelligence. Journal of Personality and Social Psychology, 41, 37-55.

Wallas, G. (1926). The art of thought. New York: Harcourt Brace.

Watson, J. D. (1968). The double helix. New York : Atheneum.

Wertheimer, M. (1959). Productive thinking. (Enlarged Edition) New York: Harper \& Row.

Corresponding author at: Charlotte L. Doyle, Psychology Department, Sarah Lawrence College, 1 Mead Way, Bronxville, NY, 10708, USA.

E-mail: cdoyle@slc.edu 